DOI: $10.21802 /$ artm.2020.3.15.79.

УДК 616.342-002.44-007.251-036.87-089

\title{
РЕКОНСТРУКТИВНО-ВІДНОВНІ ОРГАНОЗБЕРІГАЮЧІ ТА ОРГАНОЩАДНІ ОПЕРАЦІЇ ПРИ РЕЦИДИВНИХ ВИРАЗКАХ ДВАНАДЦЯТИПАЛОЇ КИШКИ
}

\author{
І.Я. Дзюбановський, Р.В. Свистун, А.М. Продан
}

Тернопільський начіональний медичний університет імені І.Я. Горбачевського МОЗ Украӥни, кафедра хірургї̈ навчально-наукового інституту післядипломної освіти, м. Тернопіль, Україна, ORCID ID: 0000-0001-8852-3938, ORCID ID: 0000-0001-6920-0770, ORCID ID: 0000-0002-6052-192X, e-mail:dzubanovsky@tdmu.edu.ua

Резюме. Ціль. Розробка сучасних та ефективних методів органощадних та органозберігаючих операцій при рецидивах виразкової хвороби дванадцятипалої кишки.

Матеріали та методи. Проаналізовано результати лікування 119 пацієнтів з виразковою хворобою ДПК, які раніше перенесли операційні втручання. Серед ускладнень переважали пілородуоденостенози - 52,9\% та рецидивні виразкові кровотечі (20,3%). А у 17,6 \% встановлено поєднання ускладнень рецидиву виразкової хвороби.

Результати. Причинами рецидиву виразки були заниження показів до радикальних і умовнорадикальних оперативних втручань під час першого втручання; неадекватна дренуюча операція; залишення виразкового субстрату в межах травного тракту; дефекти операційної техніки. Внаслідок впровадження в практику оригінальних способів операційних втручань при рецидиві виразкової хвороби ДПК отримано такі результати за A.N.Visick-Komorovsky: відмінні (відсутність скарг) - 77,5 \%; добрі (незначна диспепсія, яка виявляється лише при детальному розпитуванні і коригується дієтою) - 13,5 \%; задовільні (є симптоми, що викликають дискомфорт) - 5,6 \%; незадовільні (рецидив захворювання, зміна професії, інвалідність) - 3,4 \%.

Висновки. Органозберігаючий і органощадний підхід в реконструктивній хірургії є суттєвим засобом попередження хвороб оперованого шлунка. Суттєвим моментом у попередженні рецидиву пептичної виразки $є$ перегляд підходів до ургентної хірургії виразкової хвороби у напрямку розширення показань органозберігаючих та органощадних до радикальних та умовно-радикальних операцій на противагу "зашиванням, прошиванням" виразок. Органозберігаючі та органощадні операції дозволяють зберегти пейсмекерну регуляцію шлунка і ДПК, що в перспективі створює умови для попередження дизмоторики пілоро-дуоденальної зони.

Ключові слова: виразкова хвороба дванадцятипалої кишки, рецидив, органощадні операції

Вступ. Первинне ушивання перфорації виразки супроводжується стійкою ремісією виразкової хвороби не більше, ніж у 20-30 \% випадків, але кожний другий хворий у разі рецидивного перебігу перфорації виразки після іiі ушивання потребує повторного хірургічного втручання $[1,2,7,8]$. Рецидивні виразки зазвичай мають агресивний перебіг, ускладнюються кровотечами та вимагають негайного операційного втручання $[1,6,9]$.

Показанням до ушивання перфорації виразки $\epsilon$ термін з іiі моменту до 6 годин [3]. Є дослідження, які рекомендують виконувати радикальну операцію у разі подовження терміну з моменту перфорації до 12 год [4,5]. Проте проведений аналіз негативних результатів оперативних втручань, котрі зумовлюють необхідність виконання повторних операцій оранозберігаючого та органощадного характеру.

Обгрунтування дослідження. Саме збереження анатомічної цілісності травного каналу, фізіологічної пейсмекерної саморегуляції шлунка переконує в необхідності органозберігаючого підходу в хірургії виразкової хвороби.

Метою дослідження $є$ розробка сучасних та ефективних методів органощадних та органозберіга- ючих операцій при рецидивах виразкової хвороби ДПК.

Матеріали та методи. Проаналізовано результати лікування 119 пацієнтів з виразковою хворобою ДПК, які раніше перенесли операційні втручання (табл. 1).

Серед ускладнень рецидивних виразок були наявні (табл. 2).

Як видно $з$ таблиці 2, серед ускладнень переважали пілородуоденостенози - 52,9\% та рецидивні виразкові кровотечі (20,3 \%). А у 17,6 \% встановлено поєднання ускладнень рецидиву виразкової хвороби.

Серед додаткових методів дослідження застосовано: динамічний ЕФГДС-контроль; іонобалонотензіокінезіографію; локальний шлунковий кровобіг за методом Л.Я. Ковальчука (1984, 1987 рр.), тетраполярну реогастрографію; дослідження загального та місцевого гемостазу в умовах геморагії (тканинний тромбопластин); дослідження морфологічних змін в умовах перитоніту. 
Таблиця 1

Характер оперативних втручань

\begin{tabular}{|l|c|c|}
\hline Характер оперативних втручань & Абс. & $\%$ \\
\hline Вшивання проривної виразки дванадцятипалої кишки & 84 & 70,7 \\
\hline Прошивання кровоточивої виразки & 15 & 12,6 \\
\hline СПВ, СТв з пілоропластикою & 12 & 10,0 \\
\hline Ізольована СПВ & 8 & 6,7 \\
\hline Всього & 119 & 100 \\
\hline
\end{tabular}

Таблиця 2

Ускладнення при рецидивних виразках

\begin{tabular}{|l|c|c|}
\hline Характер ускладнень & Абс. & $\%$ \\
\hline Пілородуоденостеноз & 63 & $52,9 \%$ \\
\hline Виразкова кровотеча & 24 & $20,3 \%$ \\
\hline Повторна перфорація & 11 & $9,2 \%$ \\
\hline Поєднані ускладнення рецидивної виразки & 21 & $17,6 \%$ \\
\hline Всього & 119 & $100 \%$ \\
\hline
\end{tabular}

Результати дослідження. Причинами рецидиву виразки були заниження показів до радикальних і умовно-радикальних оперативних втручань під час першого втручання; неадекватна дренуюча операція; залишення виразкового субстрату в межах травного тракту; дефекти операційної техніки.

Характер реконструктивних операцій із 119 хворих, яким попередньо виконанні нерезекційні оперативні втручання:

- СПВ + висічення виразки +дуоденопластика - 70 хворих $(58,8 \%)$.

- Реваготомія + пілоро-або дуоденопластика - 14 $(12,7 \%)$.

- СПВ + сегментарною корпоральна резекція шлунка + пілоро- або дуоденопластика - 25 (21\%).
- Резекція шлунка за Б-I - 5 (4,2\%).

- Резекція шлунка за Гаккер-Бальфуром - 5 (4,2\%).

Органозберігаючі та органощадні операції виконані у 109 хворих - 91,6\% випадків.

У хворих $з$ декомпенсованим дуоденостенозом після попередніх операційних втручань в клініці розроблена органощадна операція після попереднього вивчення зміни товщини м'язового шару тіла та антрального відділу шлунка при змодельованому декомпенсованому пілородуоденостенозі (рис. 1).

Резекція гастродилятованого, нефункціонуючого сегменту шлунка передбачала збереження астрального відділу 3 дуоденопластикою та гастогастроанастомозом (рис. 2).

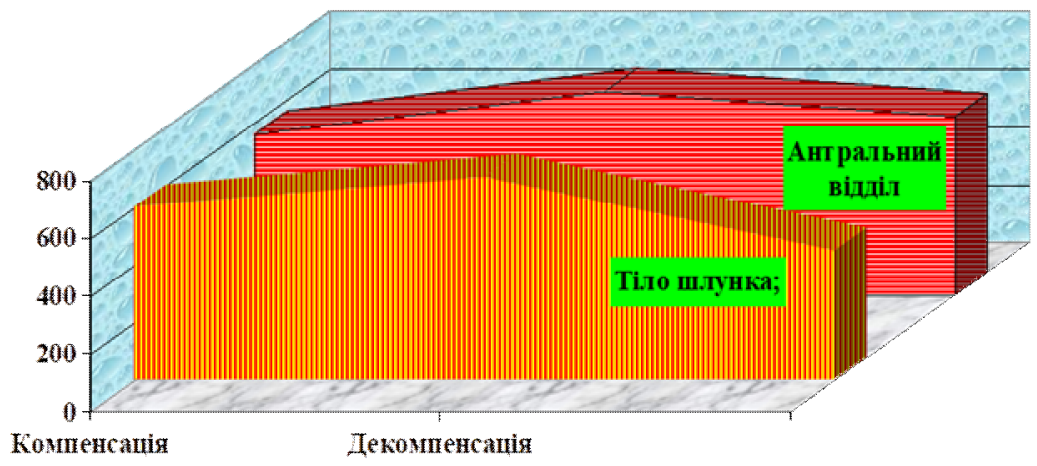

Рис. 1. Порівняльна оцінка зміни товшини м'язового шару тіла та антрального відділу шлунка при змодельованому декомпенсованому пілородуоденостеноз
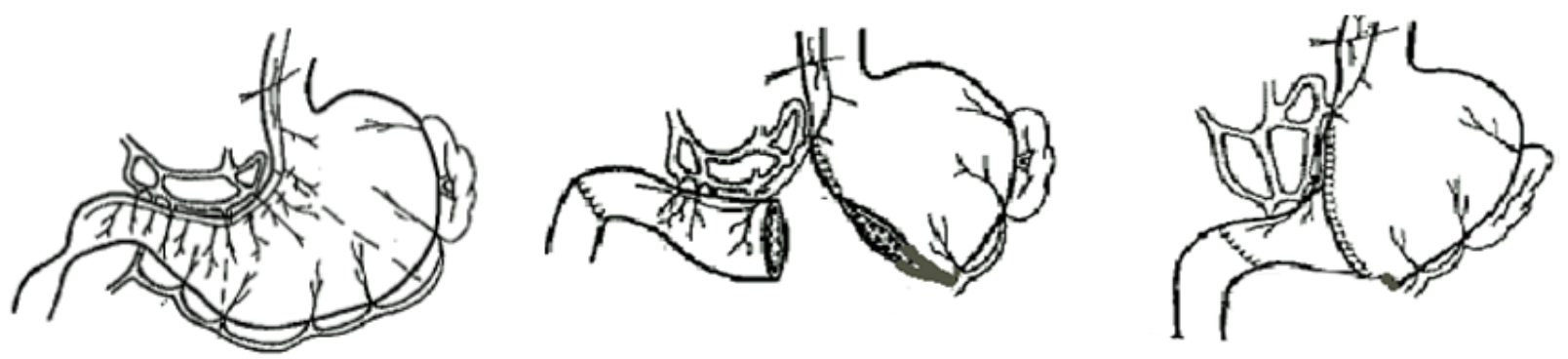

Рис. 2. Етапи операційного втручання при дуоденостенозі після попереднього вшивання перфоративного отвору виразки (Патент України № 19102 А) 
Експериментальне обгрунтування змін гастродуоденального перфоративного перитоніту

\begin{tabular}{|c|c|}
\hline \multicolumn{2}{|c|}{ Дривалість перитоніту } \\
\hline \multicolumn{2}{|c|}{ Морфологічно } \\
\hline \multicolumn{2}{|c|}{ Вогодин } \\
\hline $\begin{array}{c}\text { Вогнищеві моноорганні порушення за типом с-му } \\
\text { системної запальної відповіді (зворотній характер). } 18 \text { годин }\end{array}$ \\
$\begin{array}{c}\text { Мульторганні морфологічні зміни з дистрофічними та } \\
\text { некротичними змінами в печінці, нирках, легенях } \\
\text { (гостре пошкодження легень), дистрофія міокарду }- \\
\text { синдром поліорганної дисфункції. }\end{array}$ \\
\hline
\end{tabular}

За останні роки частота вшивання перфоративної виразки значно зменшилася і складає лише 3,8 $\%$ від усіх операцій при проривній виразці. Це обгрунтовано розширенням показань до умовнорадикальних операційних втручань на основі результатів експериментального дослідження порівняльної оцінки морфологічних змін тканин та органів за умови 18 та більше годинного перитоніту (табл. 3).
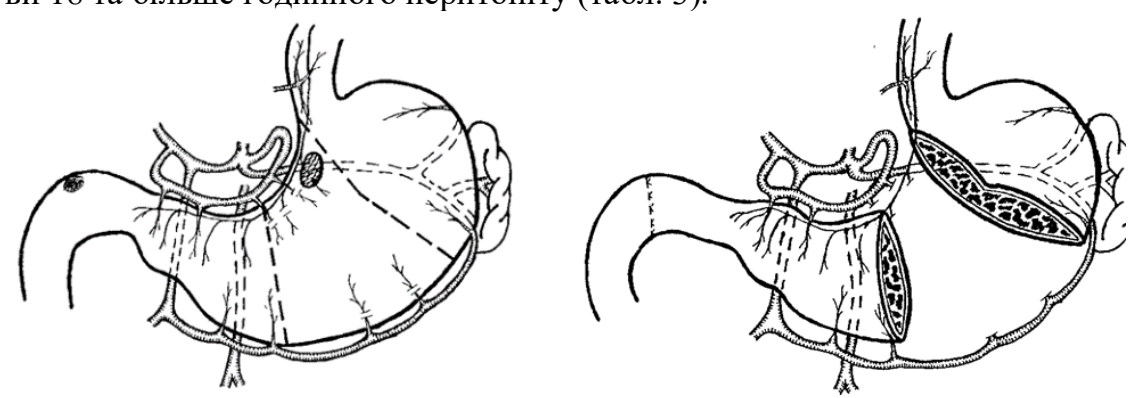

Рис. 3. Етапи операції у випадках посднаних локалізацій виразки, ускладненої кровотечею 3 виразки шлунка після попереднього вшивання виразки ДПК

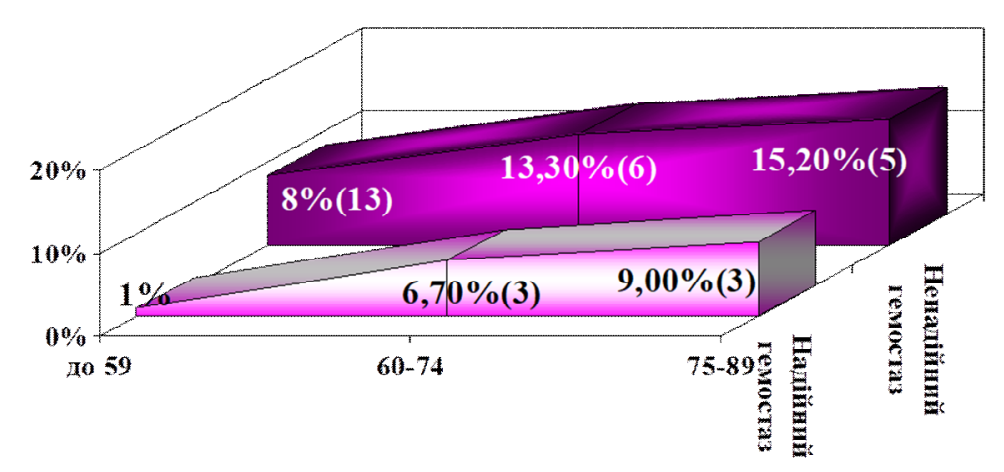

Рис. 4. Частота рецидиву кровотечі такий тип органощадних операцій, шо включає висічення виразки $з$ дуоденоплатискою, сегментарнокорпоральна резекція 3 гастро-гастроанастомозом (рис. 3).

Частота рецидивів кровотечі при різному гемостазі при поступленні вказана на Рисунку 4.

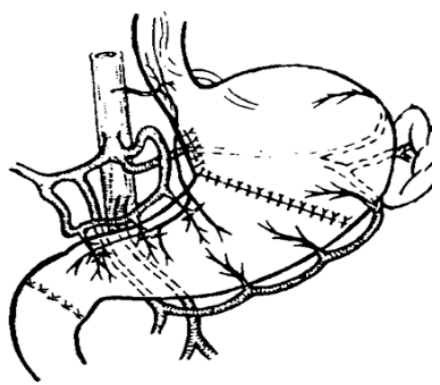

\section{Рис. 4. Частота рецидиву кровотечі}

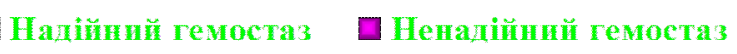

Встановлено типи активності виразкового процесу в умовах кровотечі: активні 3 високим темпом прогресування деструкції (без тенденції до зупинки кровотечі) - 3 первинно-високим дефіцитом захисних чинників, пригніченням регенерації та пластичних резервів судинного русла; активні 3 помірним та низьким темпами прогресування деструкції (з високим ризиком рецидиву кровотечі) фактори захисту та регенерації первинно знижені, 3 прогресуючим виснаженням резервів елементів захисту слизової оболонки, за рахунок ураження великих артерій та значних розладів мікроциркуляції та поширення деструктивно-некробіотичних процесів на органному рівні; активні з затухаючим перебігом (без схильності до рецидиву геморагіі), у яких в динаміці захисні та репаративні процеси активовані, деструктивні процеси обмежені ураженням на клітинному та тканинному рівнях 3 пошкодженням поверхнево розміщених дрібних та середніх артерій, розлади мікроциркуляції несуттєві.

Враховуючи типи активності виразкового процесу в умовах кровотечі нами розроблені органозберігаючі операції типу екстериторизації виразки 3 наступною пластикою за Таннер-Кеннеді (рис. 5, 6). 

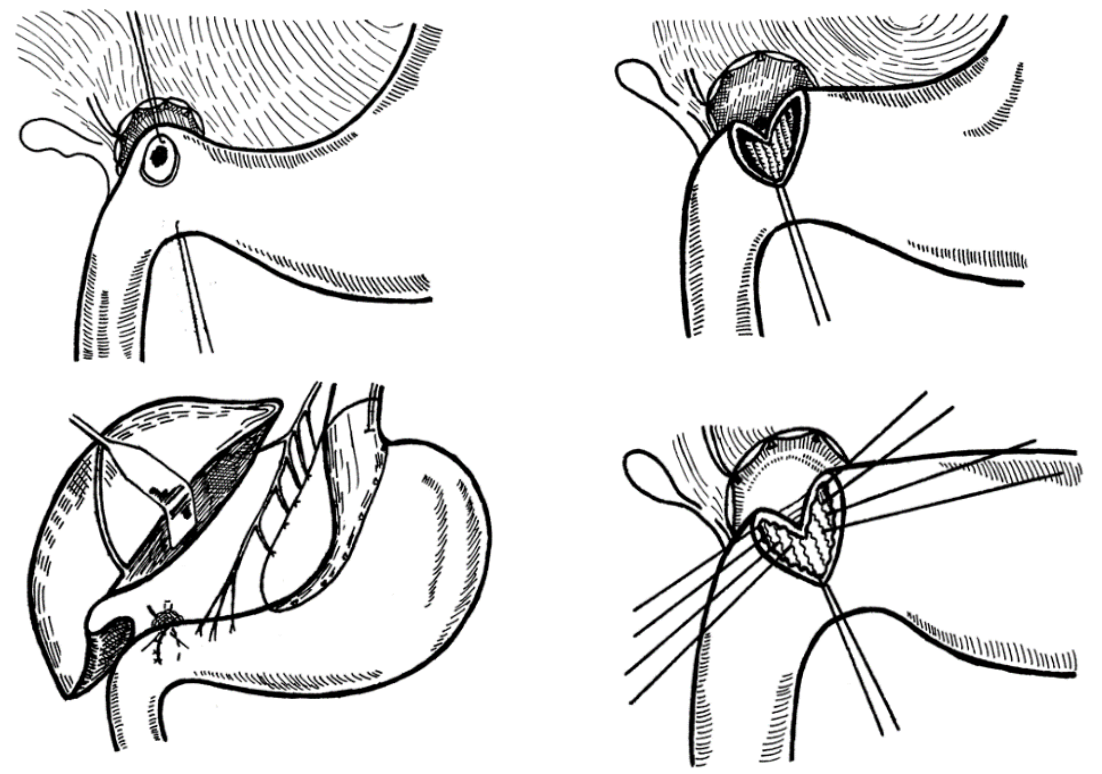

Рис. 5. Етапи реконструктивної пілоро-дуоденопластики при пенетрації виразки в гепатодуоденальну зв'язку та 3 кровотечею
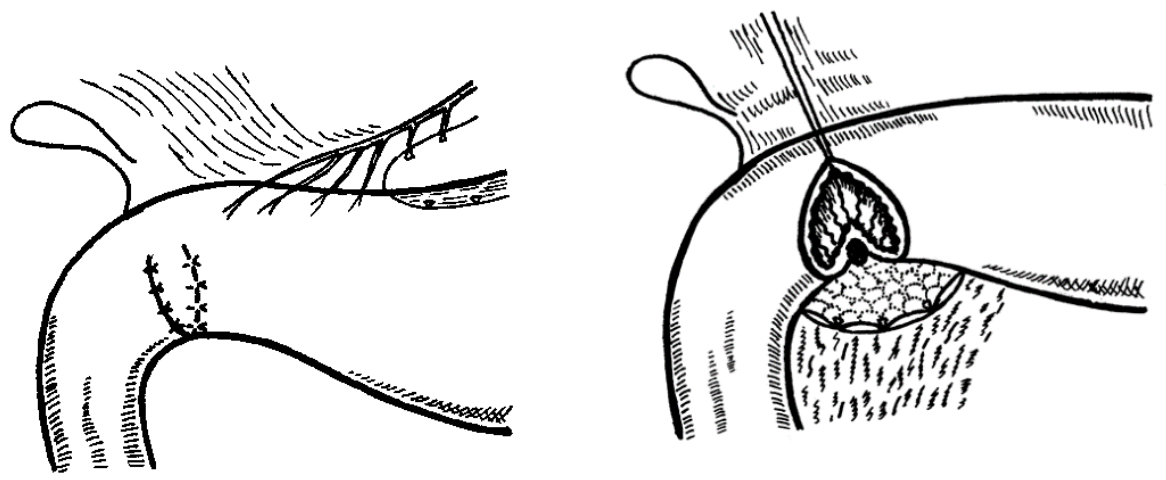

Рис. 6. Редуоденопластика при пенетрації виразки в головку підшлункової залози

\section{Komorovsky:}

Віддалені результати за A.N.Visick-

- відмінні (відсутність скарг) - 77,5 \%;

- добрі (незначна диспепсія, яка виявляється лише при детальному розпитуванні і коригується дієтою) - 13,5 \%;

- задовільні (є симптоми, що викликають дискомфорт) $-5,6 \%$;

- незадовільні (рецидив захворювання, зміна професії, інвалідність) - 3,4 \%.

\section{Висновки:}

1. Органозберігаючий і органощадний підхід в реконструктивній хірургії є суттєвим засобом попередження хвороб оперованого шлунка.

2. Суттєвим моментом у попередженні рецидиву пептичної виразки є перегляд підходів до ургентної хірургії виразкової хвороби у напрямку розширення показань органозберігаючих та органощадних до радикальних та умовно-радикальних операцій на противагу "зашиванням, прошиванням" виразок.

3. Органозберігаючі та органощадні операції дозволяють зберегти пейсмекерну регуляцію шлунка i ДПК, що в перспективі створює умови для попере- дження дисмоторики пілоро-дуоденальної зони та травного каналу в цілому.

\section{References:}

1. Ates M, Sevil S, Bakircioglu E, Colak C. Laparoscopic repair of peptic ulcer perforation without omental patch versus conventional open repair. J. Laparoendosc. Adv. Surg. Tech. A. 2007; 17(5):615-619.

2. Chung KT, Shelat VG. Perforated peptic ulcer - an update. World J Gastrointest Surg. 2017; 9:1-12.

3. Hasukic S, Konjic F, Izic S. Laparoscopic repair of perforated duodenal ulcer. Med. Arh. 2004; 58(6):380-381.

4. Klymenko VN, Vakulenko VV, Hulevskyi SN. Indyvydualyzyrovannyi podkhod $\mathrm{v}$ vybore metoda operatsyy $\mathrm{u}$ bolnykh $\mathrm{s}$ perforatyvnoi yazvoi dvenadtsatyperstnoi kyshky. Khirurhiia Ukrainy. 2004; 1:125-128.

5. Ladur AY, Popovych AYu, Kravtsova VN. Vozmozhnosty radykalnoho khyrurhycheskoho lechenyia hyhantskykh yazv zheludka y dvenadtsatyperstnoi kyshky na fone perytonyta. Klin. khir. 2008; 6:52-55. 
6. Sivaram P, Sreekumar A. Preoperative factors influencing mortality and morbidity in peptic ulcer perforation. Eur J Trauma Emerg Surg. 2018; 44:2517.

7. Søreide $\mathrm{K}$, Thorsen $\mathrm{K}$, Harrison EM, Bingener J, Møller MH, Ohene-Yeboah M, Søreide JA. Perforated peptic ulcer. Lancet. 2015; 386:1288-98.

8. Surapaneni RS, Reddy AV. The PerforationOperation time Interval; An Important Mortality Indicator in Peptic Ulcer Perforation. J Clin Diagn Res. 2013; 7:880-2.

9. Velyhotskyi NN. Khyrurhyia oslozhnennukh duodenalnukh yazv i duodenoplastyka. Kh. AFOC. 2009. P.87. 1

\section{УДК 616.342-002.44-007.251-036.87-089 РЕКОНСТРУКТИВНО- ВОССТАНОВИТЕЛЬНЫЕ ОРГАНОСОХРАНЯ- ЮЩИЕ И ОРГАНОЩАДНЫЕ ОПЕРАЦИИ ПРИ РЕЦИДИВНОЙ ЯЗВЕ ДВЕНАДЦАТИПЕРСТНОЙ КИШКИ}

\section{И.Я. Дзюбановский, Р.В. Свистун, А.М. Продан}

Тернопольский национальный медииинский университет имени И.Я. Горбачевского МЗ Украины, кафедра хирургии учебно-научного института последипломного образования,

Тернополь, Украина,

ORCID ID: 0000-0001-8852-3938,

ORCID ID: 0000-0001-6920-0770,

ORCID ID: 0000-0002-6052-192X,

e-mail: dzubanovsky@tdmu.edu.ua

Резюме. Цель. Разработка современных и эффективных методов органощадных и органосохраняющих операций при рецидивах язвенной болезни двенадцатиперстной кишки.

Материалы и методы. Проанализированы результаты лечения 119 пациентов с язвенной болезнью ДПК, ранее перенесших операционные вмешательства. Среди осложнений преобладали пилородуоденостенозы - $52,9 \%$ и рецидивирующие язвенные кровотечения $(20,3 \%)$. А в $17,6 \%$ установлено сочетание осложнений рецидива язвенной болезни.

Результаты. Причинами рецидива язвы были занижение показаний к радикальным и условнорадикальным оперативным вмешательствам во время первого вмешательства; неадекватная дренирующая операция; оставление язвенного субстрата в пределах пищеварительного тракта; дефекты операционной техники. Вследствие внедрения в практику оригинальных способов операционных вмешательств при рецидиве язвенной болезни ДПК получены следующие результаты по A.N.Visick-Komorovsky: отличные (отсутствие жалоб) - 77,5\%; хорошие (незначительная диспепсия, которая проявляется лишь при детальном расспросе и корректируется диетой) - 13,5\%; удовлетворительные (симптомы, вызывающие дискомфорт) - 5,6\%; неудовлетворительные (рецидив заболевания, смена профессии, инвалидность) $-3,4 \%$.
Выводы. Органосохраняющий и органощадный подход в реконструктивной хирургии является существенным средством предупреждения болезней оперированного желудка. Существенным моментом в предупреждении рецидива язвенной болезни является пересмотр подходов к ургентной хирургии язвенной болезни в направлении расширения показаний органосохраняющих и органощадных к радикальным и условно-радикальным операциям в противовес "починкой, прошивкой" язв. Органосохраняющие и органощадные операции позволяют сохранить пейсмекерную регуляцию желудка и ДПК, что в перспективе создает условия для предупреждения дисмоторики пилори-дуоденальной зоны.

Ключевые слова: язвенная болезнь двенадцатиперстной кишки, рецидив, органощадные операции.

\section{UDC 616.342-002.44-007.251-036.87-089 RECONSTRUCTIVE-RECOVERY ORGAN-SPARING AND ORGAN- PRESERVING OPERATIONS FOR RECURRENT DUODENAL ULCERS}

\author{
I.Ya. Dzubanovsky, R.V. Svistun, A.M. Prodan
}

I.Horbachevsky Ternopil National Medical University, department of surgery postgraduate faculty,

Ternopil, Ukraine,

ORCID ID: 0000-0001-8852-3938,

ORCID ID: 0000-0001-6920-0770,

ORCID ID: 0000-0002-6052-192X,

e-mail:dzubanovsky@tdmu.edu.ua

Abstract. Aim. Development of modern and effective methods of organ-sparing and organ- preserving operations in case of recurrence of duodenal ulcer.

Materials and methods. The results of treatment of 119 patients with duodenal ulcer disease who had previously undergone surgery were analyzed: suturing of perforated duodenal ulcer $-70.7 \%$, suturing of bleeding ulcer - $12.6 \%$, SPV, STV with pyloroplasty $-10.0 \%$, isolated SPV - 6.7\%. Among the complications of recurrent ulcers were: pyloroduodenostenosis - $52.9 \%$, ulcerative hemorrhage $-20.3 \%$, re-perforation $-9.2 \%$, combined complications of recurrent ulcer $17.6 \%$.

Additional research methods that were used: dynamic EFGDS control; ionobalonotensiokinesiography; local gastric circulation by the method of L.Ya. Kovalchuk $(1984,1987)$, tetrapolar rheogastrography; research of general and local hemostasis in conditions of hemorrhage (tissue thromboplastin); study of morphological changes in peritonitis.

Results. The reasons for the recurrence of ulcers were: underestimation of indications for radical and conditionally radical surgical interventions during the first intervention; inadequate drainage operation; leaving an ulcerative substrate within the digestive tract; defects of operating equipment. 
The list of reconstructive operations from 119 patients whom previously were performed non-resection surgery: SPV + ulcer excision + duodenoplasty - 70 patients $(58.8 \%)$, revagotomy + pyloro or duodenoplasty $14(12.7 \%)$, SPV + segmental corporate resection stomach + pyloro- or duodenoplasty - 25 (21\%), gastrectomy by Bilrot-1 - $5(4.2 \%)$, gastrectomy by Gakker-Balfour $5(4.2 \%)$. organ-sparing and organ- preserving operations were performed in 109 patients $-91.6 \%$ of cases.

In patients with decompensated duodenostenosis after previous surgery, the clinic has developed organsparing surgery after a preliminary study of changes in the thickness of the muscular layer of the body and the antrum of the stomach in simulated decompensated pyloroduodenosis. Resection of the gastrodilated, nonfunctioning segment of the stomach involved preservation of the antral segment with duodenoplasty and gastrogastroanastomosis.

In recent years, the frequency of suturing perforated ulcers has decreased significantly and is only $3.8 \%$ of all operations for perforated ulcers. This is justified by the expansion of indications for conditionally radical surgical interventions based on the results of an experimental researches of comparative assessment of morphological changes of tissues and organs under conditions of 18 or more hours of peritonitis. In $17.6 \%$ of combined complications, this type of organ-sparing operation has been developed, which includes excision of the ulcer with duodenoplasty, segmental-corporal resection with gastrogastroanastomosis. Given the types of activity of the ulcer process in the conditions of bleeding, we have developed organ-preserving operations such as the extraterritization of the ulcer, followed by Tanner-Kennedy plastics. Long-term results according to A.N. VisickKomorovsky: excellent (no complaints) - 77.5\%; good (minor dyspepsia, which is detected only by detailed questioning and corrected by diet) - $13.5 \%$; satisfactory (there are symptoms that cause discomfort) - 5.6\%; unsatisfactory (recurrence of the disease, change of profession, disability) - 3.4\%.

Conclusions. Organ-preserving and organsparing approach in reconstructive surgery is an essential means of preventing diseases of the operated stomach. Organ-preserving and organ-sparing operations allow to preserve the pacemaker regulation of the stomach and duodenum, which in the long run creates conditions for the prevention of dysmotorics of the pyloro-duodenal area.

Keywords: duodenal ulcer, recurrence, organsparing operations.

Стаття надійшла в редакцію 01. 06. 2020 р. 